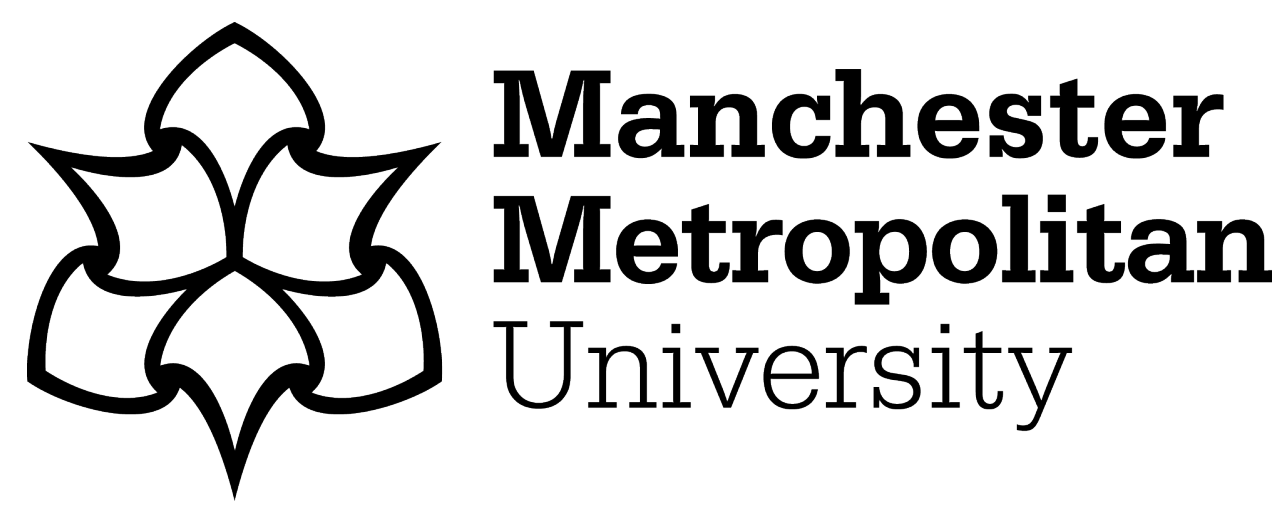

Rousell, David ORCID logoORCID: https://orcid.org/0000-0002-4509-6128 (2020) Doing Little Justices: Speculative propositions for an immanent environmental ethics. Environmental Education Research, 26 (9-10). pp. 13911405. ISSN 1350-4622

Downloaded from: https://e-space.mmu.ac.uk/621384/

Version: Accepted Version

Publisher: Taylor \& Francis (Routledge)

DOI: https://doi.org/10.1080/13504622.2018.1517408

Please cite the published version 


\title{
Doing Little Justices: Speculative propositions for an immanent environmental ethics
}

\author{
David Rousell, Manchester Metropolitan University
}

\begin{abstract}
This paper develops a series of speculative propositions for an immanent environmental ethics that is responsive to the challenges of the Anthropocene epoch. The paper is framed within a new materialist approach to environmental education, and specifically works to re-imagine the notion of justice in terms of performative gestures, multiplicities, processes, and speculative thought experiments. Drawing on Whitehead's speculative philosophy in conjunction with recent new materialist thought, the paper proposes the concept of "doing little justices" as a way of enacting micropolitical interventions into everyday patterns of environmental thought, learning, sociality, and behaviour. The concept of "little justices" is further elaborated through the analysis of vignettes that problematise issues of climate change, human exceptionalism, ecological sovereignty, and environmental justice with university students in the fields of education and the philosophy of law. The paper concludes that an immanent ethics cannot be reduced to a set of predetermined values or prescriptions for environmental education, but should proceed through a speculative process of creative experimentation and negotiation in the pursuit of unforeseen openings and potentials for coexistence.
\end{abstract}

Keywords: new materialism; Whitehead; Deleuze; immanence; environmental education; environmental ethics; Anthropocene

Citation: Rousell, D. (in press). Doing Little Justices: Speculative propositions for an immanent environmental ethics. Environmental Education Research [special issue on new materialisms].

\section{Introduction}

Recent movements in posthumanist scholarship have called for reconceptualisations of environmental education in response to the onset of the Anthropocene epoch, a time typified by anthropogenic climate change, catastrophic loss of biodiversity, ubiquitous digitisation and rapid advances in biotechnology and computer science (Lloro-Bidart 2015; Malone 2016; Payne 2016; Rotas 2015; Rousell 2016). In revealing the ontological inseparability of human culture and natural phenomena in the contemporary world, the advent of the Anthropocene has had a destabilising effect on dualistic philosophies and binary logics that have upheld ontological boundaries between the human and the nonhuman, the organic and the inorganic, the natural and the artificial, the geologic and the social (Braidotti 2013; Colebrook 2014; Ellsworth \& Kruse 2012; Haraway 2016; Yusoff 2015). In many ways the onset of the Anthropocene has acted like a "storm on thought" in environmental education, calling into question many historical "presumptions, logics and methods of reason" and forcing the field to re-evaluate "what really matters" (Payne 2016, 169). Innovative concepts and practices of environmental education are called for that can mobilise potentials for ethical thinking and action that are both attuned and responsive to the rapidly changing material conditions of everyday life (Rousell, Cutter-Mackenzie, \& Foster 2017). Such geophilosophical problematics call for a renewed consideration of justice in environmental education which admits, on the one hand, that "humans have secreted themselves into every corner of the environment", and on the other hand, "that the environment is actually inside human bodies and minds" (Bennett 2010, 116). 
In responding to the need for a renewed conception of justice in an age of climate change, this paper develops a series of speculative propositions for an immanent environmental ethics that is responsive to the challenges of the Anthropocene. Drawing together a series of emerging conceptions of justice in new materialist thought, the paper proposes the concept of "doing little justices" as a way of enacting micropolitical interventions into everyday patterns of thought and behaviour. "Doing little justices" is a concept of immanence to the extent that it proposes an ethics that is located inside material encounters, events, socialities, and occasions of experience that exceed human knowledge and understanding. To do a little justice is to perform a collective experiment within places and times of "mutual immanence" (Whitehead, 1967). Akin to what Manning (2016) refers to as a minor gesture, a little justice can be as small as a movement, a word, an image, or an idea that brings care and attention to the fragilities, entanglements, and uncertainties of life in the Anthropocene. A little justice is what Deleuze and Guattari (1986) might call a minoritarian proposition, as it plays out in the minor keys that lurk in the interstices between the majoritarian political structures and discursive social agendas of "Justice" writ large. Where majoritarian or State regimes present a "constant and homogenous system", a minoritarian politics operates through "subsystems ... seeds [and] crystals of becoming whose value is to trigger uncontrollable movements and deterritorialisations of the mean or majority" (106).

In developing the concept of little justices through this paper, I draw on the States and Territories project (2013-2016) which has collectively reimagined the learning environments of a regional Australian university in response to the Anthropocene epoch (Rousell 2017). The project involved the creation of a network of twelve environmental artworks across the university campus, each of which is connected to a specific concept and an associated digital archive on the project website: (see www.statesandterritories.org). The project was framed through a process-orientated theoretical approach and methodology, with a specialised focus on the non-anthropocentric philosophies of A.N. Whitehead $(1967 ; 1978)$ and Deleuze and Guattari $(1987 ; 1994)$. In this paper I describe how the concept of justice was re-imagined through a specific "data event" from this project, which problemetised issues of climate change, human exceptionalism, ecological sovereignty, and environmental justice with university students in the fields of education and the philosophy of law. In analysing the performative unfolding of this data event, I work to assemble an alternative conceptualisation of justice that is steeped in new materialist notions of the performative, the speculative, the collective, the processual, and the minor. In order to establish a context for my theorisation of justice within this project, the following sections provide a brief account of new materialist approaches to ethical thought and inquiry in the context of environmental education, as well as three variations on the concept of "immanence" as developed in Whitehead's (1967) later philosophical work.

\section{An Ethics of the Impossible}

The ethical value of an action is what it brings out in a situation, for its transformation, how it breaks sociality open. Ethics is about how we inhabit uncertainty, together. (Massumi 2015, 11)

The mounting social and ecological crises of the Anthropocene challenge environmental educators to assemble an entirely new imperative for ethical experimentation and inquiry in response to the mounting uncertainties of contemporary life (Zylinska 2015). Bennett $(2010,116)$ argues that the onset of the Anthropocene has eroded any possibility for the resurrection of a "pure nature unpolluted by humanity", while at the same time dissolving any meaningful endeavor to "define the self as something purely human". As Massumi suggests in the quote above, this situation calls for a 
reconceptualization of ethics in terms of processual activity that responds to changing conditions, situations, and qualities of life, rather than an ethics predicated on transcendent moral principles or universal ideals. This sense of radical openness to the immanent creativity and uncertainty of ethical relations is shared across many posthumanist philosophies of education, which are resistant to predetermined ethical frameworks or principles that delimit the possibilities for learning and inquiry (Snaza \& Weaver 2015). Yet this has also been part of the core work of certain environmental educators who have been active for many years (see, for instance, Jickling 2013; Stables 2007; Weston 1992). Harvester and Blenkinsop $(2011,123)$ also highlight the extensive genealogy of ecofeminist thought that has contested the patriarchal "logic of domination" over women, animals and environments since the 1970s, while actively promoting "nondualistic and nonhierarchical systems of relations" as alternatives to humanist metaphors, concepts and understandings of nature and the environment. This rich history of feminist critique has emphasised that concepts actually matter in environmental education, and that replacing or reconfiguring dualistic concepts of nature are crucial for the advancement of social and environmental justice (see also Braidotti 2013; 2017).

The imperative to reconceptualise environmental education has become an increasingly urgent and precarious undertaking as the Anthropocene epoch comes into focus (Malone 2016), as we find ourselves already implicated within planetary scale environmental catastrophes that exceed human capacities to understand, conceptualise, manage, or foresee (Morton 2016). In responding to ecological catastrophe on a planetary scale, Jickling $(2013,167)$ has suggested that environmental education now needs to enable learners "to grapple with issues critically and creatively and find ways to do things that currently appear impossible". As a practice of grappling with the impossible, environmental education necessarily comes to involve the creation of transdisciplinary spaces for experimenting with environmental ethics and values, rather than prescribing and predetermining certain values as environmentally ethical (168). Jickling's comments bring the function and operation of environmental education into close proximity with new materialist thought, as an ontoepistemological orientation that emphasises the situational, relational, and speculatively pragmatic nature of ethical thinking and action. Such arguments shift the role and purview of environmental education towards the creation of spaces for experimenting with a speculative "ethics of the impossible" (168). They resonate with Levi Bryant's "compositional" account of an immanent ethics that responds to junctures of crisis, as proposed in the spirit of Deleuze $(2011,27)$ :

The question of the ethical is not the question of how crisis can be ameliorated by recourse to pre-existing principles for the simple reason that the ethical is encountered at just that moment where "principles" governing a composition no longer hold. Rather, the question of the ethical is that of how situations must be re-composed in response to this moment of crisis.

In this sense, we encounter the ethical through the specificity of an event, as a moment of encounter that forces us to think and act differently in response to the unknown, the unthinkable, and the impossible.

\section{Old and New Materialisms}

It is within these moments of encounter with the impossible that new concepts become necessary to think and make the world differently, and thus to produce new kinds of events as situations of mutual encounter and co-existence. What is critically at stake in new materialist revisions of environmental education is the contested ontological status of "environment" and "education" as concepts that are inseparable from the material-semiotic conditions under which they become thinkable. When the 
concepts of "environment" and "education" are harnessed to anthropocentric, dualistic and humanist systems of thought then the practices they engender are similarly constrained; often to the point where these practices promote injustice through the unquestioned proliferation of dominant logics, inhibiting value-systems and patriarchal norms (Morton 2016; Snaza \& Weaver 2015).

Alternatively, new materialist approaches work to push concepts of "environment" and "education" to the limits of what they might include and become, with the visionary aim of opening up spaces for new modes of ethical thinking and practice to emerge. Anthony Weston (2015), for instance, has been working "the dark edges" of environmental education by expanding the concept of environment to include the Cosmic darkness of the universe beyond the boundaries of the Earth, and the Chthonic darkness that lies in the qualitative, inner powers of the Earth's landscapes and living creatures (71). Weston's dark ecological approach radically alters the scale of environmental education's ethical purview by inviting the unknowable and unthinkable elements of existence to impact on environmental ethics and pedagogical practice. In working the dark edges of environmental education and thought, Weston's (2015) approach also fosters a deep acknowledgement and consideration of Indigenous cosmologies and practices associated with animism, vitalism, totemism and magic. This exemplifies the pressing relevance of Indigenous conceptions of the environment as an emergent and actively constituted field of entangled relations, rather than a passive container or backdrop for human occupation and use (Cajete 2006; Todd 2015). Geo-ontological analyses of Indigenous art, philosophy, and culture by feminist scholars such as Grosz (2008) and Povinelli (2016) also highlight an emerging sense of compatibility between the "traditional" materialisms of Indigenous peoples and the "new" materialisms proposed by today's speculative theorists, artists, and scientific practitioners.

This convergence of "old and new" materialisms recognises the primacy of embodied experience as a constitutive process, a movement that also establishes many resonances between Indigenous knowledge systems and recent development in the life sciences (Rousell \& Williams 2018). For instance, postgenomic research in epigenetics indicates that social and physical environments affect the biological constitution of living bodies not only over the course of a single lifetime, but across generations and even across species (Frost 2016; Meloni 2016). Recent findings in embodied cognitive science further suggest that environmental and social experiences are intricately connected with biological processes, such as sensory-motor activity, directional motility, biochemical gradients, and pre-cognitive affective responses (Protevi 2013).

These dynamic notions of the "environment" as an interpenetrating series of geo-bio-cultural milieus have significant implications for how we understand the experiential, ethical, political, and pedagogical dimensions of environmental education, and indeed force us to question the very nature of "learning" as an environmentally distributed and transgenerational process. Put simply, the environment becomes the very medium and milieu through which all creatures come to learn, grow, and develop in dynamic relation to one another (Frost 2016). As noted by Frost, however, we need to be careful not to unwittingly adopt an environmental reductionism that posits all forms of life, thought, and experience as "epiphenomena" of a totally conditioning environment that operates through a linear regime of time and causality. Importantly, Frost (145) stresses the transgenerational plasticity of biological and social patterns and variations across multiple spaces and times, such that organisms are always both contemporaneous and noncontemporaneous with their immediate habitats and environments.

As a product of the many generations preceding it, an organism's habitat-responsive development and growth is noncontemporaneous with its current habitat. Those histories, as they manifest in cellular structures, protein activities, and organismic processes, set the organism apart from its habitat in the sense of providing the 
possibilities for and the constraints on the biological responses that the habitat can evoke or induce... it is this corporeal history, this noncontemporaneity, that gives a living organism its "itness" even as it composes and recomposes itself continuously in response to and through engagement with its habitat. (145)

In recalibrating our understanding of the organism-environment relation along a "differential temporal horizon" (Frost 2016, 152), the new life sciences offer important insights into the radically distributed and multi-temporal nature of environmental experience, learning, thought, and behavior.

\section{Three Variations on the Concept of Immanence}

As discussed in the previous sections, there are a number of important ethical implications currently emerging in the spaces between critical posthumanism, new materialism, environmental education, Indigenous philosophies, and the life sciences. For the purposes of this paper, I am interested in how the philosophical concept of immanence might help us to develop these lines of ethical inquiry in relation to the overwhelming environmental challenges of our times. In the process-relational philosophies of Whitehead and Deleuze, immanence is attributed (in different ways) to becoming as the ontogenetic process through which reality comes into being. ${ }^{1}$ For Deleuze (1994), there is the repetition of an immanent "difference in itself" which produces a continuity of becoming across all scales, planes, and modes of existence. For Whitehead (1978), there is a becoming of continuity that is actively produced through processual events within an immanent unity of nature as an "extensive continuum". Although these accounts of ontogenesis differ in subtle and significant ways, both Whitehead and Deleuze propose that immanence is expressed in the differential modes and manners through which things and events comes into being (Robinson 2009). For both of these thinkers, the question of the ethical comes to rest in the affective dilation or diminishing of a body's capacities to feel, sense, think, and act in the world, as well as the aesthetic qualities and forms of experience that are rendered through this process. Each of these philosophers could be said to contribute a different axiology to the concept of immanence, as the ethical and aesthetic dimensions of the concept come to fall in configurations that differ in subtle and yet important ways.

For the purposes of this paper, I would like to continue a little further with Whitehead's pluralistic account of immanence as a concept that takes on multiple variations and operational functions in his later book, Adventures of Ideas (1967). This connects the concept of immanence with the "differential temporal horizon" introduced by Frost (2016) in the previous section, as Whitehead posits different expressions and instantiations of immanence in the relations between contemporaneous and noncontemporaneous events. While Whitehead (1967) upholds a monist immanence of nature as an

\footnotetext{
${ }^{1}$ Both Deleuze and Whitehead emphasise the singular-plural nature of reality, but lean differently towards a "pure" monism and a "pluralistic" monism respectively. This difference is noticeable in their concepts of immanence, as Deleuze (2001) poses a "pure" plane of immanence that is indivisible and immanent only to itself, while Whitehead (1967) poses multiple variations and qualities of immanence in relation to nature, or the Universe, as an immanent totality. Whitehead's system of thought is ultimately a monist philosophy, but an unusual monism in which the notion of immanence is multiplied, organic, creaturely, relational, experiential, and processual (Whitehead, 1978, p. 19). Whitehead therefore leans more towards a pluralist monism than Deleuze or Spinoza. While Spinoza posits affective modes and their attributes as the manifold expressions of a single substance, Whitehead retains only the modes themselves as "sheer actualities" or "becomings" without any underlying substance. For Whitehead the basic units of reality are "actual occasions" that are self-causing and immanently creative, rather than inheriting a final causation derived from a single underlying substance (such as God, Being, nature, or matter). Hence, Whitehead attributes the emergence of complex systems (such as bodies, societies, and ecosystems) to the patterning of interconnected events within the "extensive continuum" of nature as an immanent totality, or "common world".
} 
extensive continuum that pervades and sustains all things and their relations, he also affirms a plurality of variations on the concept of immanence within this continuum. These variations can be largely attributed to his physico-mathematical theorization of multiple time systems, as he distinguishes between three temporal variations of immanence: the immanence of the past in the present as an "inherited immanence" (p. 188); the immanence of the future in the present, as what might be termed an "anticipatory immanence" (p. 192); and the "mutual immanence" that is attributed to the contemporaneous relations between two of more occasions within a given time system (p. 197). In this paper, these distinctions prove useful to the extent that they allow us to attend to the complex ethical implications of the concept of immanence as expressed through the differential relations between multiple times, spaces, events, bodies, environments, and societies.

The notion of "inherited immanence" is useful in thinking through the ethical implications of epigenetics and the agency of a conditioning environment as raised by Frost (2016) in the previous section. Not only do we inherit and express genetic codings and characteristics from the past, but we also inherit feelings, memories, thoughts, experiences, interactions, and significantly, environmental and social patterns of organization that are intricately interwoven with our everyday lives. On the one hand we inherit our own "corporeal history" (145), or "life-thread of occasions" as a "special strand of unity within the general unity of nature" (Whitehead 1967, 187). With each passing moment, we inherit the immanence of our own lifeworlds, bodies, affects, and mental states as they existed a tenth of a second ago, a day ago, a year ago, a decade ago, and so on. And yet in a certain speculative and metaphysical sense, we also inherit the immanent totality of the entire settled world, and indeed, the whole Universe as it exists at any given moment. Hence, a key ethical implication to be garnered from the notion of "inherited immanence" is that multiple occasions of the past always directly condition the present occasions in which ethical encounters occur, and through which ethical activities are carried out. Our present capacity to act is always a product of everything that we (and the whole world) have ever experienced in the past.

This brings us to the concept of "anticipatory immanence" which proposes an objectively real presence of the future within the present. Whitehead (1967) offers a number of quotidian examples to support this proposition, including the existence of legal contracts, social understandings, anxieties, and railway schedules. Without the future as a real ingredient in the present, Whitehead argues, the entire edifice of the contemporary world would fall apart. Hence, "the future is immanent in the present... as a general fact belonging to the nature of things" (194). It therefore seems safe to suggest that an "anticipatory immanence" expresses the relation between the future and the present, such that "the present bears in its own realized constitution relationships to a future beyond itself" (191). The present both contemplates and anticipates a future that is yet to come through the "real potentiality" of actual occasions as they are in the process of becoming. It is within this real potentiality of each occasion that particular ethical implications arise, as the anticipatory force of potentiality generates a modicum of causal independence or "elbow room" which grants ethical freedom to contemporary events in the passing present.

This brings us to the concept of "mutual immanence" which refers to the relations between two or more occasions of experience which are contemporaneous within the present. Whitehead (1967) writes that, "Any set of actual occasions are united in the mutual immanence of occasions, each in the other" (197). In other words, there is a mutual immanence that inheres to any event of encounter between contemporaneous things in the world, and this mutuality of contemporary relation entails both an enabling unification (each in the others) and a constraint (entanglement with others). We are both enabled and constrained by the mutual immanence of our contemporary relations with others, including the relations between those elements of our own bodies, affects, and mental states that 
constitute our existence as "living persons". For the purposes of this paper, my suggestion is that the affordances and constraints of these mutual relations implies an "immanent ethics" that inheres to each event of encounter as it occurs in the passing present. This makes every moment an opportunity to sense-, feel-, think- and act-with others in ways that are ethically attuned to the mutual immanence of co-existence within a shared environmental manifold.

\section{Reimagining the Concept of Justice}

The concept of "doing little justices" emerges from this mixed milieu of new and old materialist thought, sprouting in the cracks and intersections between process-relational philosophy, environmental education, participatory art, and the new life sciences. Thinking about ethics through Deleuze and Whitehead's philosophies helps us to conceive of justice as a "minor concept" that inheres to an immediate event of encounter, as conditioned by the immanence of the past and the future in the passing present. To do a little justice is to become attuned to this situation of mutual immanence, to acknowledge in some small way its entangled route of inheritance as well as its real potentiality, and to act in a way that creatively anticipates the necessity of a future that only becomes possible through mutual co-existence.

This re-imagining of the concept of justice was undertaken as part of my doctoral project, States and Territories, and involved a series of collaborative artworks and pedagogical experiments with university students and academics in the Philosophy of Law and Primary Education. Central to the States and Territories project has been the permanent installation of interactive artworks and multimedia interfaces across the learning environments of Southern Cross University's (SCU's) campus in Lismore, NSW, Australia. Each installation takes the form of a glass cube that maps the surrounding learning environment using photographic images captured from the object's own point of view within the landscape. These twelve cubes have operated as conceptual pivot points for a series of data events that were collectively produced with students and academics working in different units of study across the university, including units in the visual arts, media studies, cultural studies, education, law and justice, engineering, ecology, chemistry and environmental science. Each of these twelve data events has explored a different concept through curricular experimentations with new materialist ideas and practices. As shown in Figure 1, "justice" is one of twelve concepts that I explored in collaboration with university students and academics as part of the larger project, including experiments with the concepts of "becoming" and "affect" in cultural studies; the concept of "materiality" with environmental science students; and the concept of "imagining" with students in the arts and media studies. These collaborative experiments resulted in the production of a wide variety of artefacts, including videos, images, artworks, animations, sound pieces, and texts which have subsequently been archived on the project website: http://www.statesandterritories.org/archives

The cube associated with justice is located within a sloping section of landscaped garden in between the School of Law and Justice and the School of Engineering (see Figure 2). The cube is surrounded by a corridor of moss-covered trees, flowering plants, and an unusual assortment of lichens and fungi that have proliferated along the ground in this particular area. This environment changes dynamically over the course of the year, as various trees and plants flower and drop their leaves and the patterns of coloured light and shadow shift with variations in moisture, sunlight, and weather conditions. This cube is also situated in a rather dynamic social milieu, as the School of Law and Justice has become an international centre for research in the areas of Wild Law and Ecological Jurisprudence. It is within these emerging areas of study that speculative, posthumanist, and new materialist theories are beginning to exert an impact on legal philosophies, practices, pedagogies, and policy frameworks (see, for instance, Pelizzon \& Ricketts 2015). 


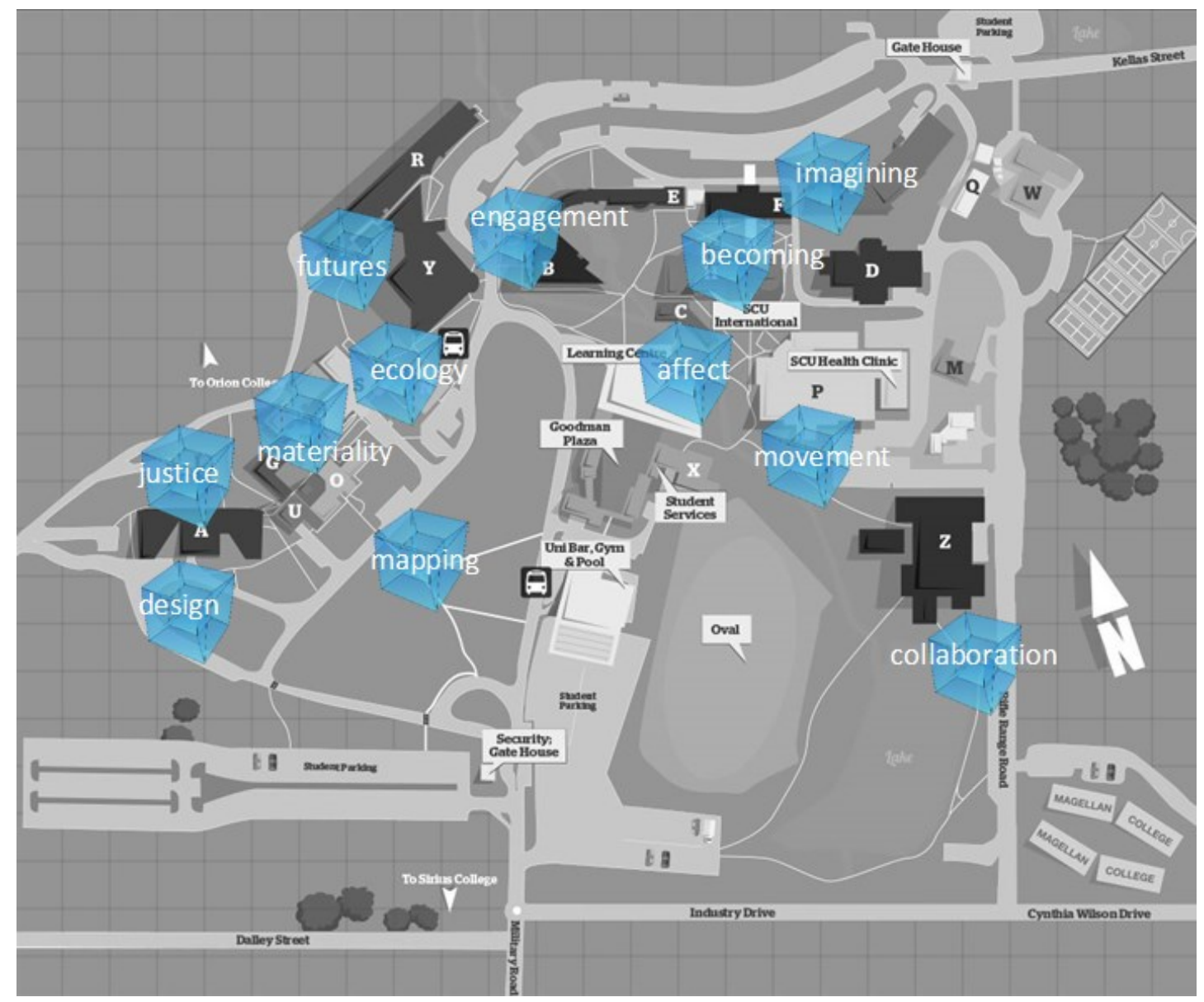

Figure 1: Network of cube locations and concepts distributed across SCU's Lismore campus

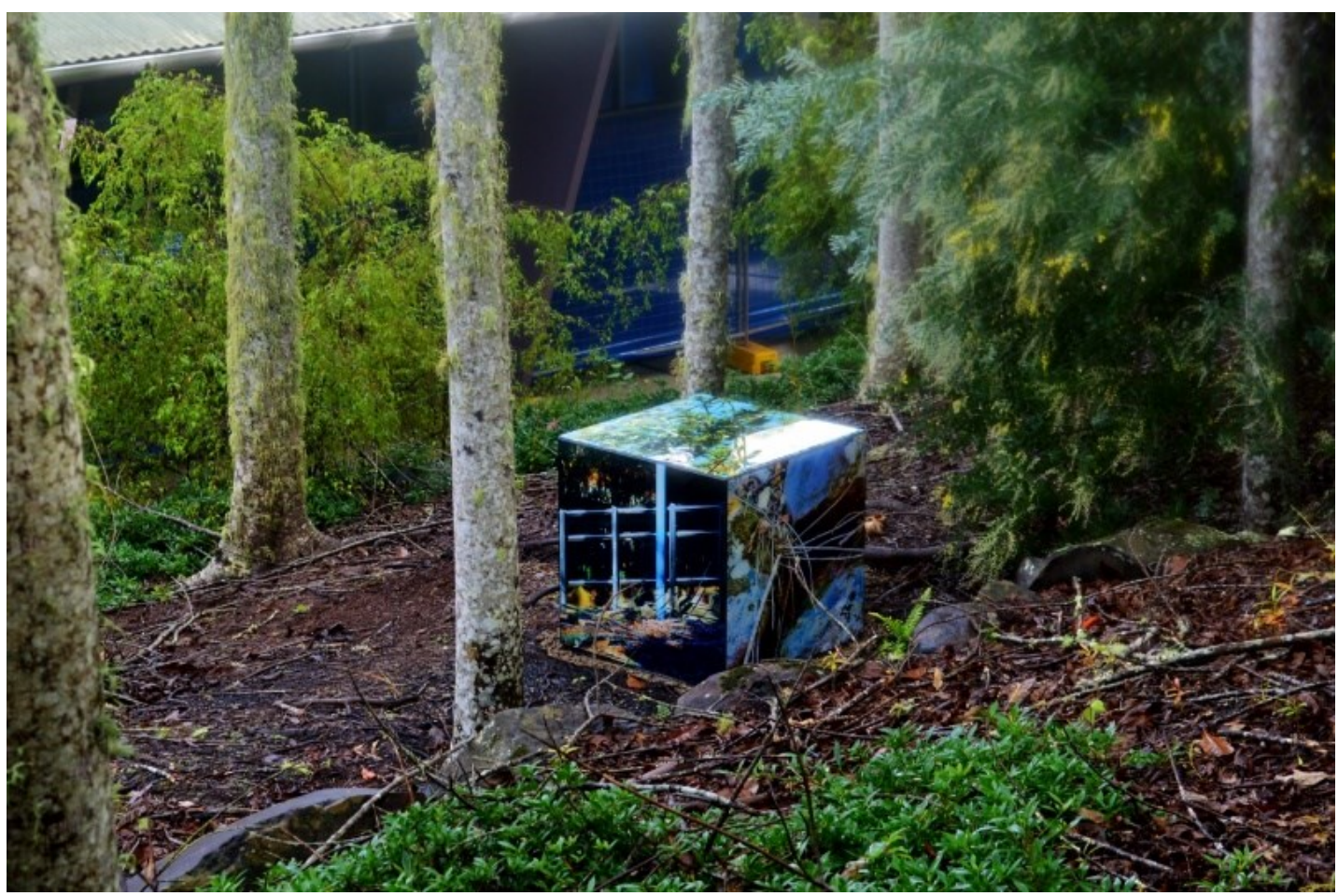

Figure 2: The justice cube is located in a stand of trees adjacent to the School of Law and Justice 
The data event associated with the Justice cube began with a series of conversations with academics in the School of Law and Justice, and the discovery that we were actually reading quite a few of the same books. Our shared interest in thinking justice beyond the human was then extended to a group of postgraduate students studying the philosophy of law, who participated in a series of seminars exploring the concept of "doing little justices" that I had been working on. The notion of "doing little justices" had emerged through my studies and experiments with new materialist theories of ecology, aesthetics, and pedagogy, and had taken shape in a series of four propositions:

1. Justice is a performative gesture by which ethical encounters are negotiated (Manning 2016);

2. Justice is a multiplicity that works 'across differences' and is 'internally differentiated, but still grounded and accountable' (Braidotti 2013, 49);

3. Justice is a process that is embodied and embedded in the actualisation of micropolitical events (Massumi 2015); and

4. Justice is a speculative experimentation that produces new forms of togetherness amongst species, practices, technologies, and modes of existence (Haraway 2016; Stengers 2005).

In my initial work with the philosophy of law students, I also connected these four propositions with environmental and socially engaged artists and artworks, including the works of Suzanne Lacy, Meirle Ukeles, and Andy Goldsworthy. We discussed Lacy's and Ukeles' "minor" interventions into social and environmental justice through their community-based installations and performances in public spaces and institutions, as well as Goldsworthy's ephemeral and subtle aesthetic interventions into wild and remote environments. We thought about how these actions constituted "little justices" which were connected to an ethics of events, encounters, and occasions of experience rather than transcendent principles or moral ideals. We also talked about simple events in our own lives that might be thought of as little justices, such as sitting outside around a fire, or exploring a part of the creek we had never seen, or engaging in the very conversations that were having. Coming out of these discussions was the idea that doing a little justice could be as simple as becoming aware of the environment as a multiplicity, and learning to sense, inhabit, articulate, and respond to this temporally and spatially distributed environment in ways that were artful, sensitive, and productive of difference.

This initial test-run of the concept of "little justices" formed the basis for a second series of seminars and collaborative activities, this time with a group of 29 primary education students undertaking a Bachelor of Education unit called Foundations: Human society and its environment. This is the core unit associated with the teaching of geography and social studies within the Australian National Curriculum, and which deals (in small part) with topics associated with sustainability, climate change, and geopolitics. For this series of seminars and activities, I focused more closely on "game changers" that the Anthropocene brings to bear on questions of justice in the primary school classroom. These game changers included:

- the detonation of the first atomic bomb in 1945, and the embedding of radionuclides within the Earth's geologic strata

- the Great Acceleration of human enterprise since 1950, including the tripling of human populations within a single lifetime and the loss of $40 \%$ of the world's animal life

- the default legal categorisation of nonhuman animals as "possessions" rather than "persons"

- the Whanganui river in New Zealand being granted the rights of a "person" in 2012, as connected with its traditional human (Maori), animal, and plant inhabitants

- the current impacts of climate change on the habitats of human and nonhuman animals alike, including the submergence of Pacific islands and glacier melts

- the rapid acceleration of biotechnology, artificial intelligence, robotics, genetics, and nanotechnology 
After discussing the ways that these game changers might impact on our understandings of justice, the students were invited to create a series of videos that expressed their attempts to grapple with these issues. Specifically, students were encouraged to explore the rights of humans in relation to animals, mountains, and rivers; the impacts of climate change on notions of social and environmental justice; and the question of what an education would be like that did not insist on human superiority and dominance. The students worked in groups with iPads and used the various environments of the university campus as the settings for their video productions. They were also made aware that these videos would be publically archived within the States and Territories website, and would be made available for future students to encounter and engage with through the Justices cube. While the range of responses to this activity was incredibly diverse, there was an unexpected consensus amongst all 29 students that the rights of a "person" should be extended to nonhuman entities such as animals, mountains, and rivers. This question of the rights of a "person" (whether in legal, ethical, psychological, or ontological terms) links to Whitehead's $(1978 ; 1967)$ expanded definition of a "living person" to include all organisms which, more or less, exhibit a "personality" as an individual within a more widely distributed ecological society. In the following brief vignettes, I offer an account and analysis of two of the more fascinating video responses produced by the primary education students. Edited versions of the videos can also be found in the Justices archive on the States and Territories website: http://www.statesandterritories.org/justice-archive

\section{First Vignette: "We can fuckin' clone them and eat the clones"}

In this video, a group of four students conduct a lively, speculative, and at times hilarious discussion in which they entertain the possibilities of nonhuman animals having political agency. They begin by asking "should an animal have the right to suffrage?", which leads them to consider the possibility that animals might democratically "elect a leader within their own kingdom" through "natural selection". The students further question the capacity for animals to communicate across species, and wonder how a "bat could talk to a dolphin". This offers an interesting example, as bats and dolphins have both evolved to use sonar as a primary communication and navigation function. This is a rare example of convergent evolution, in which species co-evolve symbiototic biological functions without having any direct contact with one another. While this discussion flirts with the fraught ethical implications of a "social Darwinism" as applied to human and nonhuman animals, it also gestures towards a political ecology in which life processes and social processes are intricately intertwined and dynamically modulated. Further connections can be made to recent developments in the ecological sciences, in which new theories of eco-evolutionary plasticity are being posed which account for variations and exchanges of genetic material within ecological systems (West-Eberhard 2003).

The students go on to suggest that the rights of humans are no more important than those of other animal species, but that humans are obligated with the responsibility of protecting the rights of other animals because they have the capacity to do so. They go on to apply this ethical proposition equally across species: "I guess once any animal becomes the top on the food chain, then it becomes their responsibility to take care of the rest of it". This offers an interesting question regarding the increased response-abilities of apex predators such as wolves, which have been shown to foster ecological rehabilitation when re-introduced into Yellowstone National Park (National Geographic Society 2017) as well as the nuclear fallout zone at Chernobyl (WNET 2016). While these examples may at first glance reinforce a hierarchical image of organisms arranged along the ecological food chain, from another perspective they gesture towards the immanent ethics of an ecological system that is dynamically modulated and re-assembled by the activities of wolves as "living persons". Rather than simply filling an empty position in the ecosystem that is preinscribed for an apex predator to manage, the wolves introduce an entire concatenation of biological, social, and mental processes that effect a qualitative transformation of the system's working as a whole. The reinvigoration of the ecosystem through the 
dynamic activities of the wolves can be considered a prime example of "doing little justices", even thought this justice is partially predicated on the wolves' capacity to consume other animals.

The students further speculate that human technologies have become so advanced that they have disconnected humans from the rest of the food chain. "We have ways to get around it; we have spaceships, we have genetic modification, we have crops that we can grow in space ... we have genetic material from cattle and sheep, we can fuckin' clone them and eat the clones". Notwithstanding the students' palpable sense of hilarity during this discussion, there is something disturbing and strange in the idea that animals might achieve the "right" to be cloned, while ethical protocols continue to prevent the cloning of humans. Would the cloning of an animal raise or diminish its status as a "person"? Would eating a clone make the consumption of animals seems less like eating a "person"? What rights do techno-scientific inventions create for the category of the "human" in relation to other animals? As a result of their certainty regarding the techno-scientific superiority of humans, the students conclude that "animals need the environment more than we do, but the environment doesn't need us at all". For these students, humanity's technological capabilities contribute to their increased ethical obligations and responsibilities to maintain the ecological systems that support other animals. At the same time, they recognise a profound alienation as the rapid evolution of technoscientific invention detaches human lives from a sense of mutual immanence with the natural world (see also Simondon 1958/2017). Furthermore, this group of students contends that human rights such as freedom of speech and freedom of movement should be attributed to nonhuman animals as "the right to roam free ... without trying to adapt animals better for our own needs". Hence, as consistent with all of the groups who participated in this series of experiments, this group argues for far more inclusive rights for animals than are commonly accorded under normative practices in Australia or under international law.

\section{Second Vignette: "Qualities of Life"}

In the second video example, three students begin by conducting a more laconic discussion of the rights that might be accorded to geographical entities such as mountains and rivers. "A lot of the rights are similar", they say. "Access to food and water, rights to reproduction, free borders for animals and water. The right to socialise with whomever you please ... qualities of life and freedom." While the students do not elaborate on the speculative implications of these rights, they do suggest that mountains and rivers could exhibit a desire for sociality, as well as the need to maintain open and porous boundaries for the movements of lifeforms and geochemical resources. They suggest that the Murray River should have the right to flow across political boundaries between States without "persecution", and allude to the river's right to maintain its own catchments without excessive drainage by farmers. It is interesting that they use the proper name of the Murray river to designate its status as a living person. The students even refer to the river as "Murray", in the same congenial sense that they might refer to a personal friend or family member. The students go on to argue that animals, mountains, and rivers should have equal rights to "qualities of life", and should not be "enslaved for their materials, or for what they're producing". Furthermore, the students identify climate change as a phenomenon that is "escalating and building up and getting mixed with other problems ... decreasing the qualities of life" by contributing directly to "diseases, lack of food, lack of free space really".

These considerations lead the students to question the mass slaughter of animals as a result of the rapid growth in human population and enterprise. "Would we like it if we killed them, I mean, if they killed us?" one student asks. This slippage in the students' questioning highlights the habitual normativity and overwhelming statistical frequency of humans killing other animals, as opposed to the relative infrequency of humans being killed by other animals. Perhaps more disconcertingly, the 
slip also highlights the zone of indiscernibility between "us" and "them": if humans are animals, then doesn't killing and eating animals entail a perverse form of cannibalism? "Would we eat meat if we didn't have that kind of mentality?" another student asks. "Maybe we would, but we would eat less. Only for survival you would. Which is what it was traditionally. Hunting down what you could for you and your family to survive". It is interesting to note that the students describe the act of eating meat as the function of a particular "mentality", rather than a biological function necessary for the acquisition of energy and nutrients. Morton $(2016,69)$ further argues that the Mesopotamian shift from a nomadic way of life to a sedentary, territorialised, and agrarian civilisation inaugurated the blind execution of what he calls an "agri-logistic mentality". For Morton, Enlightenment claims to scientific rationality and universal reason are linked to the rise of agri-logistics as an "algorithmic" mental virus that is largely subconscious, "and therefore liable to be repeated and prolonged like a zombie stumbling forward" (58). Such a subconscious mental algorithm makes the mass killing of animals both a habituated and a "logical" necessity, while the over-consumption of animals remains a primary factor in the production of greenhouse gases, soil degradation, water depletion, and the relentless destruction of oxygen-producing vegetation (McNeill \& Engelke 2014).

\section{From an Immanent Ethics to the Creation of Rights}

The two vignettes above provide brief glimpses into the modes of thinking provoked by the concept of little justices. In shifting the discourse from legal jurisprudence to an applied ethics of teacher education, the question of human and nonhuman rights becomes central to the inquiry. This shift in register brings an immanent ethics into productive tension with more normative conceptions of rights as they apply to the lives and activities "persons". Yet this does not necessarily entail a reduction of rights to transcendent humanist ideals. As Patton $(2012,15)$ argues from a Deleuzian perspective, an immanent ethics leads to the creation of new rights rather than the extension or application of axiomatic rights that somehow transcend events and occasions of experience. For Deleuze, rights are created through jurisprudence as the philosophical contemplation and expression of an ethics that is immanent within events. This becomes evident through the creation of rights with respect to biogenetic technologies, such as cloning, that produce new ontological problems and material conditions under which new rights must be invented. Such an appeal to the speculative creation of rights breaks with humanist beliefs that "individuals possess certain rights by virtue of some rightsbearing feature of human nature, such as rationality, sentience, or the capacity to act in pursuit of chosen ends" (Patton 2012, 21). Rather, there is a continuous becoming, distribution, and reassembling of rights in relation to the mutual construction of an ethical problem. The creation of rights thus occurs at the level of a subterranean micropolitics, in which consensus and dissensus come into being as coeval powers of contagion, negotiation, fostering, and invention. Similarly there appears a coeval relation between the right to exist and the right not to exist; the right to agree and the right not to agree; the right to know and the right not to know.

These productive movements from an immanent ethics to the creation of rights permeate the vignettes above, as well as the broader collection of video artefacts created by this cohort of students. Perhaps most surprising was the concurrence amongst all 29 students that the rights of a "person" should be extended to nonhuman entities such as animals, mountains, and rivers. Moreover, students were willing to make relatively radical leaps in their thinking through the creation of rights for animals to roam freely and elect chosen leaders through natural selection, or for rivers to maintain an uninterrupted flow across political borders. Whilst this could be seen as an anthropomorphic extension of human rights to animals, it was arguably the capacity for the students to re-imagine issues of justice under immanent terms that provoked them to engage so enthusiastically with the creation of rights. 


\section{Unknowable outcomes and antecedents}

By feeling, thinking, and embodying issues of justice through a speculative and affective sense of mutual immanence, students came to generate a series of aberrant and provocative ideas that connect with some of the critical concerns of environmental education and new materialist scholarship. In the case of the second vignette, for instance, there appeared to be a genuine reappraisal of the mass killing of animals as a function of blind, algorithmic execution inherited from millennia of agri-logistic practices. However, it is impossible to know the extent to which such realisations will impact on the philosophies and behaviours of students when they become classroom teachers. Can the actual "outcomes" or "results" of our research ever be known? This question becomes especially problematic when we consider the immanence of future events as they "unknowingly" participate in the constitution of bodies, places, events, and milieus in the passing present.

The problematic nature of anticipatory immanence in our research also begs the question of "unknowable" antecedents and inherited immanence. What corporeal histories could have contributed to the students' consensual agreement that all animals, mountains, and rivers should be accorded the legal status of a person? Perhaps their responses were conditioned by their engagement with different curriculum content and ideas, such as the Anthropocene thesis and the posthuman game changers associated with climate change, the Great Acceleration, and bio-genetic technologies. Maybe they were affected by asking themselves provocative questions that disrupted normative beliefs about human superiority, dominance, and exceptionalism. Perhaps their engagement with the immersive art and media of the cube network and project website had a significant effect, motivating students to articulate and archive their ideas for a future public. It's also possible that their responses were coloured by the socio-cultural milieu of Northern NSW, which is colloquially known as a haven for "green", "alternative", "spiritual", and "hippie" communities. Maybe it was simply the concept of "doing little justices" that captured their environmental imagination? The aim of all of this speculation is simply to suggest that the outcomes and antecedents of a research event can never be known because they do not follow a linear causality. Rather, they follow an emergent causal logic of the event as a novel form of collective experience, and an immanent ethics that only becomes sensible in the co-occurrence of events across multiple spaces and time systems.

\section{(In)Conclusion}

By developing and prototyping the concept of "doing little justices" as a theoretical and pedagogical figure, I have endeavoured to sketch out the contours of an environmental education that is responsive to the Anthropocene, and an immanent ethics that is embedded in the performative, speculative, collective, and minor fluctuations of a micropolitics. In lieu of claims regarding the outcomes, results, or causal antecedents of this research, I would like to propose a few pedagogical propositions that connect the events described in this paper with the broader concerns of environmental education in the Anthropocene. Firstly, the concept of "little justices" has demonstrated a pedagogical potential to produce the conditions under which immanent ethical engagements might emerge, even if only for a short time. This indicates that the concept may have pedagogical import for environmental educators who are interested in thinking-with students (animals, rivers, mountains, et al), and exploring the speculative possibilities of life, politics, sociality, and experience beyond the human. The concept should also be regarded as "portable" like a piece of modular software (Bryant 2014), in the sense that "doing little justices" can be plugged into other assemblings of disciplines, studies, concerns, practices and ideas without losing its consistency as a conceptual proposition. Secondly, I would suggest that the process of embodying the speculative possibilities of nonhuman rights and affective capacities constitutes, in itself, the enactment of a "little 
justice" that re-arranges the real potentials for new patterns of thought and behaviour to emerge. This proposition gestures towards an immanent ethics that is in and for itself (you do justice by thinking it, and think justice by doing it). And lastly, and perhaps in summary, "doing little justices" cannot be reduced to a set of predetermined values or prescriptions for environmental education. The concept needs to proceed through a speculative process of ethical experimentation and the creation of rights in the pursuit of unforeseen openings and potentials for mutual immanence. It is in this way that not knowing can become an asset, rather than a hindrance, in the ongoing pursuit of an immanent ethics for environmental education in the Anthropocene.

\section{References}

Bennett, Jane. 2010. Vibrant Matter: A Political Ecology Of Things. Durham, NC: Duke University Press.

Braidotti, Rosi. 2013. The Posthuman. Cambridge, UK: Polity Press.

Braidotti, Rosi. 2017. “Critical Posthuman Knowledges." South Atlantic Quarterly, 116:1, 83-96.

Bryant, Levi. 2011. "The ethics of the event: Deleuze and ethics without Apxń." In Deleuze and Ethics, edited by N. Jun and D. W. Smith, 21-43. Scotland: Edinburgh University Press.

Bryant, Levi. 2014. Onto-Cartography: An Ontology of Machines and Media. Edinburgh, UK: Edinburgh University Press.

Cajete, Greg. 2006. "Western science and the loss of natural creativity." In Unlearning The Language Of Conquest, edited by D. T. Jacobs, 247-259. Austin: University of Texas Press.

Colebrook, Claire. 2014. Death of the PostHuman: Essays on extinction, vol. 1. Ann Arbor, MI: Open Humanities Press.

Deleuze, Gilles, and Guattari, Felix. 1986. Kafka: A minor literature. (D. Polan, Trans.). Minneapolis: University of Minnesota Press.

Deleuze, Gilles, and Guattari, Felix. 1987. A Thousand Plateaus: Capitalism and Schizophrenia (B. Massumi, Trans.). Minneapolis: University of Minnesota Press.

Deleuze, Gilles, \& Guattari, Felix. 1994. What is philosophy? (H. Tomlinson \& G. Burchell, Trans.). New York, NY: Columbia University Press.

Deleuze, Gilles. 2001. Pure Immanence: Essays on a Life. (A. Boyman, Trans.). NY: Zone Books.

Deleuze, Gilles. 1994. Difference and repetition (P. Patton, Trans.). New York, NY: Columbia University Press.

Ellsworth, Elizabeth, and Kruse, Jaime. 2012. Making the Geologic Now: Responses to the material conditions of everyday life. Brooklyn, NY: Punctum Books.

Frost, Samantha. 2016. Biocultural Creatures: Toward a new theory of the human. Durham, NC: Duke University Press.

Grosz, Elizabeth. 2008. Chaos, Territory, Art: Deleuze and the framing of the earth. New York, NY: Columbia University Press.

Haraway, Donna. 2016. Staying With the Trouble: Making kin in the Cthulucene. Durham, NC: Duke University Press. 
Harvester, Lara, and Blenkinsop, Sean. 2011. "Environmental education and ecofeminist pedagogy: Bridging the environmental and the social." Canadian Journal of Environmental Education, 15: 120134.

Jickling, Bob. 2013. "Normalising catastrophe: An educational response." Environmental Education Research, 19 (2): 161-176.

Latour, Bruno. 2013. An Inquiry Into Modes of Existence: An Anthropology of the Moderns (C. Porter, Trans.). Cambridge, MA: Harvard University Press.

Lloro-Bidart, Teresa. 2015. "A political ecology of education in/for the Anthropocene." Environment and society, 6(1): 128.

Malone, Karen. 2016. Reconsidering Children's Encounters with Nature and Place Using Posthumanism. Australian Journal of Environmental Education, 32(01): 42-56.

Manning, Erin. 2016. The Minor Gesture. Durham, NC: Duke University Press.

Massumi, Brian. 2015. The Politics of Affect. Cambridge, UK: Polity Press.

McNeill, J.R. and Engelke, Peter. 2014. The great acceleration: An environmental history of the Anthropocene since 1945. Cambridge, MA: Harvard University Press.

Meloni, Maurizio. 2016. Political Biology: Science and Social Value in Human Heredity from Eugenics to Epigenetics. Basingstoke, UK: Palgrave Macmillan.

Morton, Timothy. 2016. Dark Ecology: For a logic of future coexistence. New York, NY: Columbia University Press.

National Geographic Society. 2017. Wolves of Yellowstone: How does wolf reintroduction benefit Earth's natural systems? Retrieved 24 January, 2017 from http://www.nationalgeographic.org/media/wolves-yellowstone/.

Patton, Paul. 2012. "Immanence, transcendence, and the creation of rights." In Deleuze and Law, edited by Laurent de Sutter and Kyle McGee, 15-31. Edinburgh: Edinburgh University Press.

Payne, Phillip. 2016. "What next? Post-critical materialisms in environmental education." The Journal of Environmental Education, 47(2): 169-178.

Pelizzon, Alessandro, and Aidan Ricketts. 2015. "Beyond anthropocentrism and back again: from ontological to normative anthropocentrism." Australasian Journal of Natural Resources Law and Policy 18 (2): 105-125.

Povinelli, Elizabeth. 2016. Geontologies: A requiem to late liberalism. Durham, NC: Duke University Press.

Robinson, Keith. 2009. "Introduction: Deleuze, Whitehead, Bergson- Rhizomatic connections." In Deleuze, Whitehead, Bergson- Rhizomatic connections, edited by Keith Robinson, 1-27. Basingstoke, UK: Palgrave Macmillan.

Rotas, Nikki. 2015. "Ecologies of praxis: Teaching and learning against the obvious." In Posthumanism and educational research, edited by Nathan Snaza and John Weaver, 91-104. New York, NY: Routledge. 
Rousell, David. 2017. "Mapping the Data Event: A posthumanist approach to art/education/research in a regional university". Arts, Research, Education: connections and directions, edited by Linda Knight and Alexandra Cutcher, 203-220. New York: Springer International Publishing.

Rousell, David. 2016. "Dwelling in the Anthropocene: Re-imagining university learning environments in response to social and ecological change". The Australian Journal of Environmental Education, 32(2): $1-20$.

Rousell, David, and Williams, Dilafruz. 2018. "Ecological Aesthetics: New spaces, directions, and potentials". In Research Handbook on ChildhoodNature, edited by Amy Cutter-Mackenzie, Karen Malone, and Elizabeth Barrat-Hacking. The Netherlands: Springer.

Rousell, David, Cutter-Mackenzie, Amy, and Foster, Jasmyne. 2017. "Children of an Earth to Come: Speculative fiction, geophilosophy and climate change education research". Educational Studies, 53(6): 654-669.

Snaza, Nathan, \& Weaver, John. 2015. "Introduction: Education and the posthumanist turn." In Posthumanism and educational research, edited by Nathan Snaza and John Weaver, 1-16. New York, NY: Routledge.

Stables, Andrew. 2007. "Is nature immaterial? The possibilities for environmental education without an environment." Canadian Journal of Environmental Education, 12(1): 55-67.

Stengers, Isabelle. (2005). "Introductory Notes on an Ecology of Practices". Cultural Studies Review. 11(1): 183-196.

Todd, Zoe. (2015). "Indigenizing the Anthropocene". In Art in the Anthropocene: encounters among aesthetics, politics, environments and epistemologies, edited by Heather Davis and Etienne Turpin, 241-254. London: Open Humanities Press.

West-Eberhard, Mary. 2003. Developmental plasticity and evolution. Oxford, UK: Oxford University Press.

Weston, Anthony. 1992. "Before environmental ethics." Environmental Ethics, 14(4): 321-38.

Weston, Anthony. 2012. Mobilising the green imagination: An exuberant manifesto. BC, Canada: New Society Publishers.

Weston, Anthony. 2015. "Working the dark edges." Canadian Journal of Environmental Education, 19: 70-79.

Whitehead, Alfred North. 1967. Adventures of Ideas. New York: The Free Press.

Whitehead, Alfred North. 1978. Process and reality. New York: The Free Press.

WNET. 2016. "Radioactive wolves." Retrieved 26 January, 2017 from http://www.pbs.org/wnet/nature/radioactive-wolves-introduction/7108/.

Yusoff, Kathryn. 2015. Geologic subjects: Nonhuman origins, geomorphic aesthetics and the art of becoming inhuman. Cultural Geographies, 22(3): 383-407.

Zylinska, Joanna. 2014. A minimal ethics for the Anthropocene. Ann Arbour, MI: Open Humanities Press. 
